\title{
TIME, PRESENCE, AND HISTORICAL INJUSTICE
}

\section{BERBER BEVERNAGE}

For what seems apparent in former Yugoslavia, in Rwanda and in South Africa is that the past continues to torment because it is not past. These places are not living in a serial order of time, but in a simultaneous one, in which the past and present are a continuous, agglutinated mass of fantasies, distortions, myths and lies. . . Crimes can never be safely fixed in the historical past; they remain locked in the eternal present, crying out for vengeance. ${ }^{1}$

\section{ABSTRACT}

The relationship between history and justice traditionally has been dominated by the idea of the past as distant or absent (and with that, irreversible). This ambiguous ontological status makes it very difficult to situate the often-felt "duty to remember" or obligation to "do justice to the past" in that past itself, and this has led philosophers from Friedrich Nietzsche to Keith Jenkins to plead against an “obsession” with history in favor of an ethics aimed at the present. History's ability to contribute to the quest for justice, as a result, often seems very restricted or even nonexistent. The introduction of the "presence"-paradigm in historiography can potentially alter this relation between history and justice. However, to do so it should be conceived in such a way that it offers a fundamental critique of the metaphysical dichotomy between the present and the absent and the underlying concept of time (chronosophy) that supports this dichotomy. The “presence”-paradigm can be emancipatory and productive only if presence and absence are not perceived as absolute dichotomies. In the first part of this article I elaborate on the influence that the present/absent dichotomy has on the notion of justice by introducing a conceptual contrast

\footnotetext{
${ }^{1}$ Michael Ignatieff, “Articles of Faith,” in Index on Censorship 5 (1996), 110-117.
} 
between what I will call the "time of jurisdiction" and the "time of history." The second part of the article focuses on the way certain aspects of the dominant Western chronosophy reinforce the present/absent dichotomy and thereby prevent us from thoroughly exploring the ambiguous but often very problematic presence of the past. Throughout the article I refer to the relatively recent phenomenon of truth commissions and the context of transitional justice to discuss some challenges for the "presence”-paradigm.

\section{INTRODUCTION}

Several philosophers already have noted the temporal dimensions of our conception of the relation between history and justice. ${ }^{2}$ The most explicitly pronounced and opposed positions in the debate undoubtedly are taken by Friedrich Nietzsche and Walter Benjamin. For Nietzsche, history always must serve life and the future; it should not strive to achieve historical justice. ${ }^{3}$ He scorns the widespread obsession with the past—-that consuming fever of history-and envies the cattle that, fettered to the moment, live unhistorically, in contrast to humankind, which is buried by the ever-increasing burden of what is past. To be able to live, he insists, humankind must abandon the hope for justice and must learn to forget, but "it requires a great deal of strength to be able to live and to forget the extent to which to live and to be unjust are one and the same thing.",

\footnotetext{
${ }^{2}$ I would like to express my gratitude to Chris Lorenz, Eelco Runia, Gita Deneckere, and Jan Art for interesting
} discussions and for providing me with valuable commentary on drafts of this article. I would also like to thank the group of philosophers of history around Veronica Tozzi at the Universidad de Buenos Aires, especially Cecilia Macon and María Inés La Greca, for taking the time to read and discuss this text.

${ }^{3}$ Friedrich Nietzsche, “On the Uses and Disadvantages of History for Life,” in Nietzsche, Untimely Meditations (Cambridge, UK: Cambridge University Press, 1997), 57-124.

${ }^{4}$ Nietzsche, however, does preserve a place for memory and the idea of justice after all: Sometimes "this same life that requires forgetting demands a temporary suspension of this forgetfulness; it wants to be clear as to how unjust the 
In contrast, the prominent cultural philosopher Walter Benjamin, in his well-known “Theses on the Philosophy of History," took an unreserved stance in favor of the innumerable victims of historical injustice still covered by the piling wreckage of the past. ${ }^{5}$ He defends an "anamnestic solidarity” between the living and the dead, arguing that living generations should not aim at the future but at preceding generations in their striving for justice. ${ }^{6}$ Because past generations anticipated the generation currently living, Benjamin argues that the living possess a "weak messianic power" to redress the injustices of a catastrophic past.

At the root of these opposed stances are radically different conceptions of the past and its ontological status. Traditionally the relationship between history and justice is dominated by the idea that the past is distant or absent (and with that, unalterable). This ambiguous or even inferior ontological status of the past has led several philosophers, following Nietzsche, to plead against an "obsession" with history and to argue instead for an ethics aimed at the present. ${ }^{7}$ The idea of the past as absent makes it very difficult to situate the frequently felt "duty to remember" or

existence of anything—a privilege, a caste, a dynasty, for example—is, and how greatly this thing deserves to perish.” Every past is worthy of being condemned, but only they who build the future may preside at the tribunal. Ibid., 76.

${ }^{5}$ W. Benjamin, “Theses on the Philosophy of History,” in Benjamin, Illuminations (London: Fontana Press, 1992).

${ }^{6}$ This term was only posthumously introduced by Christian Lenhardt in “Anamnestic Solidarity: The Proletariat and its Manes,” Telos 25 (1975), 133-154.

${ }^{7}$ Keith Jenkins defends an argument like this in his own variation on the end-of-history theme. He writes that “. . .the need to bother with the past at all—not least for ethical purposes—is questionable: that perhaps we don't need what we might call a 'historical consciousness’ anymore.” Keith Jenkins, “Why Bother with the Past? Engaging with Some Issues Raised by the Possible 'End of History as We Have Known It',” Rethinking History 1:1 (1997), 56-66. The idea that the past as history can be demanding is discussed in G. Bennington, “Demanding History,” in Post-Structuralism and the Question of History, ed. Derek Attridge, Geoffrey Bennington, and Robert Young, (Cambridge, UK: Cambridge University Press, 1987), 15-29. 
alleged obligation to "do justice to the past” in that (demanding) past itself. History’s ability to contribute to the quest for justice, as a result, often seems very limited or even nonexistent.

More attention has been paid lately within the philosophy of history to the "presence" of the past—as manifested, for example, in Eelco Runia’s introduction of the “presence”-paradigm in this journal. This reconsideration of the (ontological) status of the past can radically alter the relation between historians and "their” past. It can make it possible for history to contribute more substantially to the search for justice. Moreover, it is relevant to a current international political reality, namely, the problematic "presence” of a traumatic and often explosive past in countries trying to recover from violent conflict, such as South Africa, Argentina, Chile, and Sierra Leone. The ubiquitous turn to the past and to memory in such countries has resulted in disputes over reparations and in the establishment of truth commissions, and represents an enormous challenge for historians and their discipline. ${ }^{8}$

The "presence”-paradigm, however, can be emancipatory and productive only if presence and absence are not perceived as absolute dichotomies. One should not think about fixed

${ }^{8}$ History as an academic discipline has been developing within the context of a distinctively modern concept of time that, according to Reinhart Koselleck, was typified by an increasing rupture between experiences of the past and expectations about the future (in his terms, respectively, “space of experience” and "horizon of expectation”). Against the backdrop of this worldview that was saturated by historical change and the belief in progress, history was obsessed above all with absence and loss, and aimed at a (scrupulous) conservation of the "fleeting” past. Yet the contemporary context of a past that does not want to go, in which a realistic horizon of expectation for large parts of the world population unfortunately almost coincides with a (tragic) space of experience, and in which the expiring of (cosmological) time does not necessarily create an experience of distance from the past, confronts historians with a totally altered situation. In this context the traditional notion of historical time seems no longer useful, or at least should be modified radically. See Reinhart Koselleck, Futures Past: On the Semantics of Historical Time (New York: Columbia University Press, 2004).

Hans Gumbrecht has remarked that this absence of the notion of distance in imagining the relation with the past is typical for presence and what he calls presence-culture. See H. U. Gumbrecht, "Presence Achieved in Language (With Special Attention Given to the Presence of the Past),” History and Theory 45 (October 2006), 323. 
categories of the absolutely absent or the absolutely present; "presence" should not be understood as the antonym of absence (this of course makes the term a little unfortunate ${ }^{9}$ ). Ewa Domanska has recently criticized the dichotomous classification of present versus absent, and has proposed a way of conceiving presence and absence that avoids dichotomizing them. ${ }^{10}$ In this article, I will focus mainly on how the present/absent dichotomy is related to differing notions of time and justice. Underlying the present/absent dichotomy, I argue, is a specific concept of time. Any analysis of the "presence" of the past must, therefore, be combined with a radical critique of the dominant concept of historical time and the metaphysical presuppositions and ontological commitments that accompany it. While I am very enthusiastic about the recent “presence”-debate as far as it opens a new way of thinking about history, I fear that "presence” could turn into an obscure metaphysical or even "mystical” category if it is not firmly embedded in a criticism of the notions of historical time and the "historical present."

This article, therefore, analyzes how particular aspects of the modern concept of a linear, pointillist time as a collective singular hinders our ability to think about the "presence” or persistence of the past. I will analyze how this chronosophy ontologically privileges the present and forces the present/absent dichotomy upon us. Ultimately, by referring to Jacques Derrida’s notion of spectral time, I will discuss some aspects of an alternative chronosophy that can sustain a notion of "presence" that transcends the present/absent dichotomy and that thereby affords us a

\footnotetext{
${ }^{9}$ While I myself would prefer another more metaphysically neutral word to refer to the survival or stubborn
} persistence of the past, I will use Runia’s term “presence” for sake of the debate. To stress the contrast that ought to be drawn between a critical "presence"-paradigm and the metaphysical dichotomy between absolute absence and absolute presence, I will refer subsequently to the ambiguous, impure, or spectral presence of the past as "presence."

${ }^{10}$ She uses Algirdas Julien Greimas’s semiotic square to dissolve the absolute contrast between present and absent by adding the less-opposing categories of the non-absent and the non-present. E. Domanska, “The Material Presence of the Past,” History and Theory 45 (2006), 337-348. 
better understanding of haunting pasts. This alternative chronosophy will, in turn, underwrite a far more acceptable account of historical justice.

\section{TIME OF HISTORY, TIME OF JUSTICE}

Before I start the critique of Western chronosophy and the way it forces us to think in the mutually exclusive terms of the present and the absent, let me elaborate a little further on how this dichotomy determines the traditional relationship between history and justice-or, more exactly, between the discipline of history and the discipline of jurisprudence. The French historian Henry Rousso noted in an interview that historians have traditionally seen the proper time for history as the inverse of the proper time for justice. While the law decrees that the possibility of prosecuting or punishing expires after a certain amount of time (with the important exception of crimes against humanity), the historian supposedly should begin work only after a certain waiting period, often after the dead are buried and the archives are unsealed. ${ }^{11}$ Rousso rejects this notion of a waiting period but does not seem to realize that the temporal antagonism between history and justice is rooted much more deeply than appears at first sight. The conflict between the time of jurisdiction and the time of history (I refer here to history as a discipline or as historiography) can be interpreted as an antagonism deriving from their respective emphasis on presence and absence, and with the re- or irreversibility of the event at stake. The time of jurisdiction frequently assumes a reversible time in which the crime is, as it were, still wholly present and able to be reversed or annulled by the correct sentence and punishment. This concept of time holds a narrow economic logic of guilt and penalty, in which justice ultimately is understood as retribution and atonement. History, in contrast, works with that which has happened and now is irretrievably gone. It stresses "the arrow of time," makes use of a

\footnotetext{
${ }^{11}$ Henry Rousso, The Haunting Past: History, Memory, and Justice in Contemporary France (Philadelphia:
} University of Pennsylvania Press, 2002), 30. 
fundamentally irreversible time, and forces us to recognize the dimensions of absence and the unalterability of the past. History's concept of time challenges justice's: the "retribution" of justice never can be swift enough to completely reverse or undo the damage done, because every crime is always already partly in the past and thus always displays a dimension of absence. This makes it impossible, within history's concept of time, to bring complete justice after time has elapsed. Whoever strives for a vaster moral mandate for history (in the name of the victims of the past) will sooner or later confront its concept of time. Max Horkheimer used exactly this concept of time as a fearsome weapon in his criticism of the eschatological and anamnestic philosophy of his friend Walter Benjamin. The idea of perfect justice, according to Horkheimer, is a recurring illusion that stems from a primitive idea of exchange. ${ }^{12}$ It is unthinkable that perfect justice can be realized within the realm of history, because even a perfectly just society never can compensate for the misery of the past. The historical past is Nichtwiedergutzumachende; “[p]ast injustices are over and done with. The murdered really are murdered.”13

The time of history is right to criticize this "primitive idea of exchange" that underlies the ideally reversible time of jurisdiction. Both Levinas and, in his wake, Derrida, have argued that the time of suffering and historical injustice is not economical, not quantifiable, and cannot be used in a system of exchange. ${ }^{14}$ Yet does this concept of time not overstate the absence of the past? Does it not neglect dimensions of "presence" or persistence of the past and its injustices? The emphasis on the absence and irreversibility of past and historical injustice endows the time

${ }^{12}$ Max Horkheimer, “Thoughts on Religion,” in Horkheimer, Critical Theory: Selected Essays (New York: Herder and Herder, 1972), 179-180.

${ }^{13}$ From a letter to Benjamin (1937). Cited in Helmut Peukert, Science, Action, and Fundamental Theology (Cambridge, MA: The MIT. Press, 1984), 206-207.

${ }^{14}$ J. D. Caputo, “No Tears Shall Be Lost,” in The Ethics of History, ed. David Carr, Thomas R. Flynn, and Rudolf Makkreel (Evanston, IL: Northwestern University Press, 2004). 
of history with something uncomfortable, something unjust and almost unacceptable in a moral sense. It is exactly against this time, which "threatens to destroy all morality," that the Belgian/Austrian Auschwitz survivor Jean Améry rebels in his notorious essay "Resentments" (1966). ${ }^{15}$ Améry shocked his contemporaries by pleading against forgiveness and future reconciliation in favor of resentment, and by demanding a "moral inversion" of time. He encouraged resentment but also realized that it and its backward temporal orientation are in fundamental conflict with some of the most dominant ideas concerning the irreversible character of time: "the time-sense of the person trapped in resentment is twisted around, dis-ordered, if you wish, for it desires two impossible things: regression into the past and nullification of what happened.”16 However, as a captive of the moral truth, Améry demands a right of resistance against what he calls the anti-moral "natural" or "biological” time that heals all wounds:

What happened, happened. This sentence is just as true as it is hostile to morals and intellect. . . . The moral person demands annulment of time-in the particular case by nailing the criminal to his deed. Thereby, and through a moral turning-back of the clock, the latter can join his victim as a fellow human being. ${ }^{17}$

Améry took an explicit stance against Nietzsche’s counsel to learn to forget and his notion that history must serve the present and the future. He also, almost prophetically, announced a modern version of this debate, which has (re)appeared on the international political stage with full strength and high urgency when a growing number of nations trying transition to

${ }^{15}$ G. Van den Berghe, “Tussen wrok en verzoening,” in Nieuw Wereldtijdschrift (2000), 60-68.

${ }^{16}$ Jean Améry, At the Mind’s Limits: Contemplations by a Survivor on Auschwitz and its Realities (Bloomington: Indiana University Press, 1980), 68.

${ }^{17}$ Ibid., 72. 
democracy had to reckon with a dark and violent past of dictatorship and civil war. Often, these situations of political transition-usually characterized by a combination of high moral capital and low bureaucratic capacity ${ }^{18}$ — seem to manifest a weighty practical, political, and moral dilemma: on the one hand to restore historical injustice and thereby to risk social dissent, destabilization, and a return of violence; or on the other to aim at a democratic and peaceful future to the "disadvantage" of the victims of a grim past. ${ }^{19}$ Predictably, most perpetrators of historical injustice choose the second option. Both F. W. de Klerk and Augusto Pinochet, for example, plead for forgetting in the name of the future and reconciliation. ${ }^{20}$ Historically, advocates of political amnesia_often combined with a certain degree of amnesty-are numerous and weighty. ${ }^{21}$ Conscious forgetting frequently is defended in the name of democracy and emancipation. Remembrance of and retribution for the past then become subordinated to a future-oriented policy. The most radical formulation of this position is Bruce Ackerman's plea to

\footnotetext{
${ }^{18}$ Bruce Ackerman, The Future of Liberal Revolution (New Haven: Yale University Press, 1992), 72.

19 Ibid.

${ }^{20}$ See, for example, the following statement by De Klerk: “The best way to reconcile would be to say: Let’s close
} the book of the past, let's really forgive and let's now start looking at the future” (cited in C. Braude, “The Archbishop, the Private Detective and the Angel of History: The Production of Public Memory and the Truth and Reconciliation Commission,” Current Writing 8 [1996)], 2, 57). Consider also the plea for forgetting by Pinochet: "Both sides should forget. We must continue working for Chile, for our republic; we should not look back. Let's not allow this country to become a third-class nation but a second- or first-class one if possible. But to achieve that it is necessary to be intelligent, capable, and to have the ability to forget” (cited in P. De Greiff, “The Duty to Remember: The Dead Weight of the Past, or the Weight of the Dead of the Past?” [Unpublished paper prepared for presentation at Instituto Latinoamericano de Salud Mental y Derechos Humanos (ILAS), Chile, February 7, 2002]).

${ }^{21}$ Several European peace treaties — from the treaty of Lothar in 851 to the treaty of Lausanne in 1923—called for an act of forgetting. So did the French constitutions of 1814 and 1830 . The English Civil War also ended with an Act of Indemnity and Oblivion. Timothy Garton Ash, “The Truth about Dictatorship,” New York Review of Books 45, no. 3 (February 19, 1998), 35-40. 
forget the illusion of corrective justice and to burn the "stinking carcasses" in the official archives. ${ }^{22}$ Stuck in the temporal dichotomy that was described above, the only reasonable alternative for some_-given the impossibility of falling back on the traditional legal repertoire of prosecution and punishment, and given the fear of a dividing and traumatizing historiographyseems to be a combination of amnesty and amnesia. Given this dichotomizing of the present and the absent, Ignatieff's claims (cited at the outset of this essay) about a past that continues to torment because it is not past, about the non-serial time of places like Yugoslavia, Rwanda, and South Africa, and about crimes that cannot be safely fixed in historical time, cannot be taken seriously. History's concept of time forces us to interpret the victim's recurring stress on the “presence” of the past as merely figurative language. When victims or relatives fail to achieve justice shortly after the crimes are committed, we see how a stress on the absent and irreversible dimensions of the past promotes the attitude of letting "bygones be bygones.”

The struggle against impunity and the search for new and alternative forms of justice, therefore, almost automatically leads toward a blurring and questioning of the schism between the concepts of time held by the disciplines of justice and history. The relatively recent phenomenon of the truth commission — which cannot convict as a real tribunal but, depending on its mandate, nevertheless may pronounce some judgment about the past—developed in response to the "transitional justice dilemma" that many nations face as they transition to democracy. The truth commission is a hybrid that is situated at the intersection of justice and history. A fragile political situation, which often makes it very difficult to prosecute the offenders, forces truth commissions to search for alternative or "soft" forms of justice that are found in the realm of history and its concepts of "historical truth” and "remembrance.”23 The introduction of (public) remembrance and truth-telling as alternative forms of justice is accompanied by an implicit

\footnotetext{
${ }^{22}$ Ackerman, The Future of Liberal Revolution, 81.

${ }^{23}$ L. Huyse, Alles gaat voorbij, behalve the verleden (Leuven: Van Halewyck, 2006), 53.
} 
rejection of the quasi-reversible time of justice and a recognition that all injustice is, fundamentally, irreversible. At the same time, it is precisely the emphasis on the endurance of historical injustice and on the presence of the past that allows truth commissions to resist amnesia and blanket amnesty and to transform remembrance and historical truth into forms of justice.

The "presence"-paradigm is a welcome improvement on the long-standing disregard for the ambiguous presence of the past within the time of history. Nonetheless, as long as it is positioned within the context of the present/absent dichotomy it threatens to digress into the mythical reversibility of the time of justice. Therefore, the remainder of this article is dedicated to a critique of the time concepts that force us into this dichotomy, and to the formulation of an alterative chronosophy. This alternative should pay attention to dimensions of presence as well as dimensions of absence of the past; and it should allow historians to engage in the current quest for different kinds of justice.

\section{CRITICIZING THE TIME OF HISTORY}

Time and temporality have always occupied center stage in the history of Western metaphysics. Time concepts have been used to classify phenomena and to distinguish ontological categories ever since Greek antiquity. For Plato and many medieval thinkers, eternity or timelessness constituted the most important aspect of reality. With the emergence of modern thought, the emphasis moved toward timeliness and finitude as central characteristics of the real. ${ }^{24}$ How one thinks about time greatly influences one's thinking about other concepts or objects and their ontological status. However, the highly naturalized and reified character of the modern concept

${ }^{24}$ Quentin Smith and L. Nathan Oaklander, Time, Change and Freedom: An Introduction to Metaphysics (London: Routledge, 1995), 3; and E. Jonathan Lowe, The Possibility of Metaphysics: Substance, Identity, and Time (Oxford: Clarendon Press, 1998), 84. 
of time makes it appear to be so natural that it becomes virtually invisible, thereby obscuring the metaphysical presuppositions and “ontological commitments” that accompany it. ${ }^{25}$

In the preceding part of this article I elaborated on the way a variation of the presence/absence dichotomy gave rise to an antagonism between what I called the time of jurisdiction and the time of history and their respective conceptions of justice. To respond to the question of how this dichotomy itself originates in a notion of time and to realize which aspects of the dominant Western chronosophy restrict our ability to think about the "presence" of the past, I turn to R. G. Collingwood and his notes on the philosophy of history. ${ }^{26}$ Collingwood's theory concerning the re-enactment of the past-his version of the "presence"-paradigm ${ }^{27}$ forced him to reconsider the ontological status of the past. His notion of history involves the existence of a living past that has some kind of presence in the present. Collingwood's emphasis on "presence" in history contrasts with the popular interpretation of historicity as flux or radical alterity. The time concept of the natural sciences, interpreted by Collingwood as based on pure sequence or changeability and wherein the past disappears without leaving any residue, according to him, can result only in "pseudo-history" or mere chronology. In the historical process of becoming, he argues, the past is actually preserved as an element in the present. This can take the form of an accumulation of knowledge, experience, tradition, and so on, and

${ }^{25}$ Because of its naturalized character, modern time could be interpreted as a myth in the sense recently described by Frank Ankersmit in this journal. Time as a modern myth constitutes the ultimate limit of that which historians succeed in historicizing. Time is considered to be the transhistorical condition of all history and change. For historians, it makes up the link with nature, which has no history itself. See Ankersmit, "Presence and Myth," History and Theory 45 (October 2006), 333.

${ }^{26}$ R. G. Collingwood, The Principles of History and Other Writings in Philosophy of History, ed. W. H. Dray, and W. J. van der Dussen (Oxford: Oxford University Press, 1999).

${ }^{27}$ This has already been noted by Rik Peters in his “Actes de présence: Presence in Fascist Political Culture,” History and Theory 45 (October 2006), 362-374. 
certainly cannot be reduced to a simple function of human memory. For that reason, Collingwood urges, the time of history should be understood to involve some kind of transtemporal vestige of the past in the present, and time should not be imagined as a mere sequence: "The past is not merely the precondition of the present but a condition of it."28

Now, which aspects of time make us conceive of historicity as flux or pure alterity and in this way keep us from thoroughly understanding this ambiguous survival of the past? A combination of three essential features of the dominant chronosophy seems to prevent historians from fully accepting the phenomenon of "presence" in history. One is the metaphysical dominance of the geometrical point in the regnant Western concept of time; the second is the idea of time as a collective singular; the third feature is related to the first two: thinking about time on the basis of the absolutely self-contemporaneous present. The metaphysical dominance of the point, undoubtedly, is the most central characteristic: time is, both in common sense and scientific discourse, usually imagined as a linear continuum of instants or now-points. This representation of time, according to the Italian philosopher Giorgio Agamben, can be traced back to the Greek experience of time that finds its most explicit formulation in Aristotle. Aristotle defined time as a "quantity of movement according to the before and the after," and he assured its continuity by dividing it into discrete instants [now-points] analogous to the geometric point. An isolated instant has no length of its own and is reduced to a pure limit that both unites and divides past and future. The ambiguous and elusive character of time then must be situated in the paradox that in dividing time infinitely, the now is always "other," while in uniting past and future and in consolidating its continuity it is always the same. Agamben relates the destructive character of time, which he terms "radical otherness," to this idea of "fleeting instants."29

\footnotetext{
${ }^{28}$ Collingwood, The Principles of History, 130.

${ }^{29}$ Giorgio Agamben, “Time and History: Critique of the Instant and the Continuum,” in Agamben, Infancy and History: The Destruction of Experience (London: Verso, 1993).
} 
It is in the context of this idea of a destructive, devouring, or rapacious (Augustine) time with its "fleeting instants" that the dominant conceptualization of history should be understood. Against this background, history is always precarious and chased by an ever-threatening loss. Destructive time grants only a very restricted ethical mandate to history: the present, robbed by destructive time, becomes past after it is consumed, is irreversible, and can never be changed. History, therefore, can offer only the slender consolation of truth and remembrance in the face of the worst atrocities of the past.

For this reason, every attempt to develop an alternative chronosophy that leaves some conceptual space for the ambiguous persistence or "presence” of the past necessarily must deal with this Aristotelian inheritance and must criticize the concept of the now-point. The representation of the present as analogous to the (discrete) geometrical point, according to Agamben, is the opening through which metaphysics insinuates itself into the human experience of time. It forces us, as Sandra Rosenthal remarks, into a pseudo-choice between absolute identity and absolute alterity —an antagonism that is closely related to our present/absent dichotomy. ${ }^{30}$

The destructive character of time is reinforced still more by its elevation into a collective singular - in which events are collected as in a container - that excludes any idea of noncontemporaneity, anachronism, or local persistence of the past. The notions of a singular “historical present” and of absolute historical synchronicity, according to Louis Althusser, are rooted in a metaphysical freezing of time. ${ }^{31}$ This intellectual operation, where one makes a vertical incision at a moment in time to reveal a historical present, he calls an essential cut (coupe d'essence). Althusser especially criticizes the implicit conceptions of society and

${ }^{30}$ Sandra B. Rosenthal, Time, Continuity, and Indeterminacy: A Pragmatic Engagement with Contemporary Perspectives (Albany: State University of New York Press, 2000).

${ }^{31}$ Louis Althusser and Etienne Balibar, Lire le Capital I (Paris: Maspero, 1968). 
historical totality that are presupposed by such a cut: a totality in which all elements are linked and simultaneously present in their essence and effect, a totality that becomes decipherable synchronically. He denies the existence of an absolute present and subordinates his concept of time to his layered conception of history, where each social formation (economy, politics, religion, aesthetics, philosophy, and so on) characterizes itself by its own temporality. His Marxist conception of a complex social totality prevents him from gathering all social processes relevantly in one and the same historical time. The rejection of an absolute, universal "container time” enables him to elaborate on the idea of a plurality of relatively autonomous histories and allows him to reject the concept of one universal history.

This is certainly not an outrageous idea. Indeed, Reinhart Koselleck has argued that the introduction of the idea of a coherent totality, which we call history, is a relatively recent event. ${ }^{32}$ While the basic elements and aporias in our metaphysical thinking about time, as Agamben argues, go back to the Greek, its treatment as an autonomous and objective all-embracing phenomenon originates in Newton's concept of absolute time and space. ${ }^{33}$ Pre-Newtonian

\footnotetext{
${ }^{32}$ Until the eighteenth century, this concept of a singular history as the collection of all histories, res gestae and
} vitae, was absent. The development of the concept of history as a unique event or universal relation of events, at least for the German language, has to be situated semantically around 1750 in the passage from the term "Historie" to "Geschichte." Koselleck, Futures Past, 32.

33 Newton defined time in his Principia Mathematica [1687] as follows: “Absolute, true, and mathematical time, of itself, and from its own nature, flows equably without relation to anything external, and by another name is called duration: relative, apparent and common time, is some sensible and external (whether accurate or inequable) measure of duration by the means of motion, which is commonly used instead of true time; such as an hour, a day, a month, a year.” Cited in Philip Turetsky, Time (London: Routledge, 1998), 73. Newton's concept of absolute time has mostly been abandoned in modern physics since Einstein's theory of relativity was introduced. In the human and social sciences, though, it is still dominant. For a discussion of the implications of the contemporary models of time in the natural sciences for the human and social sciences, see Barbara Adam, Time and Social Theory (Cambridge, UK: Polity Press, 1990). The 
thinkers used a relational concept of time, based on historical events and historical change, and they consequently did not know the concept of absolute time as an all-embracing container. ${ }^{34}$ Lacking an integrating absolute chronology, pre-Newtonian thinkers often saw no reason to synchronize or temporally relate events that showed no obvious interactions. “A dating system presuming that any two events had only one possible quantitative temporal relationship and could thus be synchronized unequivocally would have been as inaccurate in the eyes of Herodotus and Thucydides as their relative dating is primitive in ours.” ${ }^{35}$

Althusser appropriately asserts that concepts such as "synchronic,” “diachronic,” and "historical present” are metaphysical constructs, and he shows how a particular concept of time reflects fundamental conceptions of history and historical totality. ${ }^{36}$ His claim about the temporal complexity of the historical present ultimately led him to formulate a specifically Marxist “overdetermined" dialectic that should break with the Hegelian dialectic of simple contradiction. A Marxist dialectic should carefully study the phenomenon of "survival” in history, without reducing it to a Hegelian supersession or "Aufhebung." "There can be no doubt that these

concept of an absolute time in fact already predates Newton, but only became dominant in the West after his time. For an overview of the intellectual struggle between partisans of a relational time and partisans of an absolute time before Newton, see Milic Capek, “The Conflict between the Absolutist and the Relational Theory of Time before Newton,” Journal of History of Ideas 48:4 (1987), 595-608.

${ }^{34}$ As Donald J. Wilcox remarks: "Scholars now enjoy the luxury of complaining that centuries are meaningless as indicators of major changes, but they could not even decry the use of such epochs if they had no sense that abstract quantities could contain and characterize a group of events occurring within them.” Donald J. Wilcox, The Measure of Times Past: Pre-Newtonian Chronologies and the Rhetoric of Relative Time (Chicago: University of Chicago Press, 1987), 9.

${ }^{35}$ Ibid., 74.

${ }^{36}$ Fredric Jameson has also criticized the dichotomy between synchronic and diachronic. He considers it to be a distortion of time from a spatial perspective, and warns us neither to confuse the diachronic with time and history nor to interpret the synchronic as being static. Fredric Jameson, “The End of Temporality,” Critical Inquiry 29 (2003), 698. 
survivals exist-they cling tenaciously to life,” Althusser wrote. Nonetheless, they remain virtually uninvestigated. ${ }^{37}$

Seen from this point of view, history is not necessarily unifying and does not always place the diverse human experiences of the past within one framework. Just like competitive (collective) memories, it allows for antagonism, pluralism, and fragmentation. ${ }^{38}$ The idea frequently held in truth commissions, that historical truth-telling automatically contributes to reconciliation and social unity, is therefore not really persuasive. The revaluation of the noncontemporaneous, the anachronistic, and combinations of local change and changelessness, should enable us to move toward a conceptualization of the "presence" and persistence of the past in a way that transcends the simple present/absent dichotomy with all its moral implications.

\section{SPECTRAL TIME}

In order to imagine a historiography that addresses the problem of the persistence or survival of the past (as it has been formulated by Althusser), one can turn to the later work of Jacques

${ }^{37}$ Louis Althusser, “Contradiction and Overdetermination,” in Louis Althusser, For Marx (New York: Vintage Books, 1970), 114. The problem of nonsynchronism in relation to dialectics had already been addressed earlier in the Marxist tradition by Ernst Bloch. Along lines that show a lot of similarity (but also important differences) to Althusser's arguments, Bloch famously claims the Gleichzeitigkeit des Ungleichzeitigen and defends a kind of "polyphonous” dialectics. "Thus, in order for one to become master of the nonsynchronous, the problem of a multi-level dialectics emerges. Obviously, the entirety of earlier development is not yet 'sublated' in capitalism and its dialectics.” Ernst Bloch, “Nonsynchronism and the Obligation to Its Dialectics,” New German Critique 11 (1977), 22-38.

${ }^{38}$ A similar rejection of time as a unifying collective singular was formulated much earlier by Horkheimer, as follows: "The claim that reality is essentially indivisible contradicts the fact distinguishing history, at least in its form until now, that humanity is divided into the happy and the unhappy, the ruling and the ruled, the healthy and the sick.” Max Horkheimer, “On Bergson’s Metaphysics of Time,” Radical Philosophy 131 (2005), 15. 
Derrida for inspiration. ${ }^{39}$ In his Specters of Marx, Derrida sets out to seriously think through "the persistence of a present past or the return of the dead which the worldwide work of mourning cannot get rid of." ${ }^{40}$ He introduces the figure of a specter or ghost coming from the past or the future to haunt the present. Scholars, according to Derrida, have rarely addressed the problem of spectrality because of its uncanny and "undecidable" characteristics that resist the sharp distinction between the real and the unreal, the living and the dead, or-most importantlybetween what is present and what is absent (that is, what is present and what is past). ${ }^{41}$

Still, just when no ethics or politics seems possible, thinkable, and just without respect for or recognition of those who are not presently living (whether already dead or not yet born), it is

\footnotetext{
${ }^{39}$ In an interview with Jean-Louis Houdebine and Guy Scarpetta, two Marxists from the Tel Quel group, Derrida
} explicitly says he always subscribed to Althusser's criticism with regard to the Hegelian concept of history, the notion of expressive totality. He calls Althusser's rejection of a single or general history and his claim about the existence of a plurality of differentiated histories an “indispensable body of criticism” (Guy Scarpetta and Jean-Louis Houdebine, “Positions: Interview/Jacques Derrida,” Diacritics 2 [1972], 42). Derrida shares Althusser’s strong criticisms of the Hegelian idea of Aufhebung and stresses several times that we must break with this Hegelian metaphysical concept in order to "think our relation to (the entire past of) the history of philosophy otherwise than in the style of dialectical negativity, which—as a tributary of the vulgar concept of time-posits an other present as the negation of the present pastretained-uplifted in the Aufhebung, where it yields its truth”39 (Jacques Derrida, “Ousia and Gramme: Note on a Note from Being and Time,” in Jacques Derrida, Margins of Philosophy [Chicago: University of Chicago Press, 1982], 38). “Were there a definition of différance,” Derrida writes elsewhere, "it would be precisely the limit, the interruption, the destruction of the Hegelian sublation everywhere that it is operative” (Scarpetta and Houdebine, "Positions,” 35).

40 Jacques Derrida, Specters of Marx: The State of the Debt, the Work of Mourning, and the New International (New York: Routledge, 1994), 101.

${ }^{41}$ One should indeed consider the specter to belong to a set of concepts that Derrida himself calls "undecidables" "which escape from inclusion in the philosophical (binary) opposition and which nonetheless inhabit it, resist and disorganize it, but without ever constituting a third term, without ever occasioning a solution in the form of speculative dialectics” (Scarpetta and Houdebine, “Positions,” 36). 
more necessary than ever, Derrida claims, "to speak of the ghost, indeed to the ghost and with it.” ${ }^{42}$ However, according to Derrida the spectral cannot be contemplated as long as one relies on the modern historical concept of time as a series of successive "presents" or "nows" that are absolutely identical and contemporary with themselves. Hamlet's famous declamation that the time is "out of joint" inspires Derrida to claim the "non-contemporaneity with itself of the living present." $^{43}$ His spectral logic elaborates on a critique of modern time that transcends the present/absent dichotomy, and that is highly challenging for historians and their imagination of the past, the event, and the historical present. ${ }^{44}$

While Specters of Marx is generally considered to represent a break in Derrida's workseparating the more outright political "later Derrida” from the “earlier Derrida”a spectral time can clearly be situated within his overarching life-project of criticizing the Western "metaphysics of presence." The idea of spectrality is closely related to the deconstructive logic of différance-Derrida’s now-classic master concept that binds together the spatio-temporal dimensions of difference and deference. Différance denies the possibility of any identity being wholly present, and it poses some questions of the Heideggerian type by criticizing the authority of presence and its "simple symmetrical opposite" of absence. ${ }^{45}$ The whole history of Western philosophy, according to Derrida, has been influenced by a certain

\footnotetext{
42 Derrida, Specters of Marx, xix.

${ }^{43}$ Ibid.

${ }^{44}$ While it has often been proclaimed that Derrida takes a stance against history, he himself stresses his critique is
} directed only against a certain metaphysical conception of history. If Derrida has been using his deconstructive procedure to attack the "archeo-teleological” concept of history (in the line of Hegel, Marx, and Heidegger) it is only to show how it neutralizes or even cancels historicity. Derrida, in his own words, to the contrary wanted to develop another way to think about historicity, one that would welcome spectrality, one that enables him to rethink the idea of the historical event and the historical present. Ibid., 75.

45 Jacques Derrida, “Différance,” in Margins of Philosophy (Chicago: University of Chicago Press, 1982), 10-11. 
conception of time that puts too much emphasis on the present and the actual to the disadvantage of the absent (non-present) and the inactual. Derrida repeats and radicalizes a critique that Martin Heidegger had already hinted at: he opposes the reduction of all forms of Being to forms of "presence" (Anwesenheit), understood in regard to a definite mode of time: the present (Gegenwart). ${ }^{46}$ From Parmenides to Husserl, he writes, the privilege of the present has never been questioned. Even non-presence is always considered in relation to presence or as a modalization of presence. The past and the future, too, are often determined as past presents or as future presents. Derrida, therefore, approvingly cites Heidegger when the latter writes, “The vast reach of presencing shows itself most oppressively when we consider that absence, too, indeed absence most particularly, remains determined by a presencing which at times reaches uncanny proportions. ${ }^{47}$

A very specific determination of time has thus implicitly governed the determination of the meaning of Being in the history of philosophy. "Traditional ontology," according to Derrida, can therefore "be destroyed only by repeating and interrogating its relation to the problem of time.”48 Heidegger clearly sensed this but, according to Derrida, somehow refused or did not dare to elaborate on the radical "temporal clue" that could destroy all metaphysics. While Sein und Zeit subjects classical ontology to an "extraordinary trembling” by radically criticizing the "vulgar" linear concept of time that pursues the analogy with the point and the line by unmasking how it determines Being as presentness, its own proposition of a more "authentic" primordial time that constitutes the transcendental horizon of Being, according to Derrida, "still remains

\footnotetext{
${ }^{46}$ Derrida, “Ousia and Gramme,” 31.
}

47 The original quotation by Derrida appears in German in "Ousia and Gramme” (31). The English translation here is taken from John Protevi, Time and Exteriority: Aristotle, Heidegger, Derrida (Lewisburg, PA: Bucknell University Press, 1994), 84.

${ }^{48}$ Derrida, “Ousia and Gramme,” 47. 
within the grammar and lexicon of metaphysics." 49 Derrida at one point even considers the Heideggerian problematic to be the "deepest" and "strongest" defense of what he calls the thought of presence. ${ }^{50}$

In his early essay "Ousia and Gramme," Derrida in fact starts from a footnote in Heidegger's Sein und Zeit to develop his own radical critique of the Western concept of time. Just like Heidegger, Derrida criticizes the long tradition, stretching from Aristotle to Hegel, of conceiving and conceptualizing time from the metaphysical idea of the "now"/present. However, he endeavors to offer a kind of counter-reading of the thinkers whom Heidegger criticizes, in order to show that the great texts of metaphysics are not only about the so-called "vulgar" concept of time but also contain the elements to deconstruct this conception of time from within. Unlike Heidegger, Derrida goes beyond an analysis or description of the paradoxes and aporias in the history of metaphysics to discern a possibility of a radically different concept of time right at the heart of this tradition. Aristotle, according to Derrida, not only founded a long tradition of metaphysical thinking but also delivered the tools to deconstruct this tradition and its "vulgar" concept of time.

Just like Agamben, Derrida situates the most important aporias of the metaphysical conception of time on its use of the point-like "now" that both divides time infinitely and gives it the continuity of a line. While Aristotle knew very well about these aporias, and even explicitly

${ }^{49}$ Ibid., 63.

${ }^{50}$ Scarpetta and Houdebine, "Positions,” 41. While this seems to be a very negative evaluation, Herman Rapaport remarks that Derrida has, in fact, taken many different positions on his relation to Heidegger, sometimes stressing the close relation between the latter's intellectual project and deconstruction, at other times warning against any confusion between deconstruction and Heideggerian thought. "Hence any static distinction made between Derridean deconstruction and Heideggerian philosophy will quickly be perceived to be inadequate, since the relationships between these modes of thinking shift their positions or proximities over time” (Herman Rapaport, Heidegger \& Derrida: Reflections on Time and Language [Lincoln: University of Nebraska Press, 1989], 7-10). 
exposed them in his exposition of the commonsense concept of time, he never really answered the questions he himself raised. The long history of metaphysical thinking, according to Derrida, is constituted by this omission and is possible only by endlessly evading these questions on the nature and the Being of time. ${ }^{51}$ Much like Althusser, Derrida especially resists the metaphysical idea of the point-like—absolutely synchronic_present or now because it excludes the possibility of any non-contemporaneity or spectrality:

Coexistence has meaning only in the unity of a single, same now. . . . One cannot even say that the coexistence of two different and equally present nows is impossible or unthinkable: the very signification of coexistence or of presence is constituted by this limit. Not to be able to coexist with an other (the same as itself), with an other now, is not a predicate of the now, but its essence as presence. The now, presence in the act of the present, is constituted as the impossibility of coexisting with an other now, that is, with an other-the-same-as-itself. ${ }^{52}$

It is precisely this impossibility of the coexistence of two nows, according to Derrida, that falls prey to an internal paradox and in his words can only be experienced as the "possibility of the impossible." "The impossibility of coexistence can be posited as such only on the basis of a certain coexistence, of a certain simultaneity of the nonsimultaneous, in which the alterity and identity of the now are maintained together in the differentiated element of a certain same.”53

This "certain same” actually can be expressed by the Greek word hama, which means something like "together," “all at once," or "at the same time." The whole possibility of

\footnotetext{
${ }^{51}$ Derrida, “Ousia and Gramme,” 47.

${ }^{52}$ Ibid., 54-55.

${ }^{53}$ Ibid., 55.
} 
deconstructing time from within the tradition of metaphysics, then, comes down to a little word that was used hardly five times by Aristotle but, according to Derrida, provides "the small key that both opens and closes the history of metaphysics in terms of what it puts at stake." ${ }^{54}$ While Aristotle did not explicitly refer to the meaning of this word, and even tried to hide it, it betrays an unconscious logic of the discontinuous, nonlinear, or plural into his conception of time. This “temporal clue,” according to Derrida, should make it possible to think a concept of time that is no longer dominated simply by a present or a "now" that has the impossibility of coexisting with the non-contemporaneous as its essence. Hama introduces a dimension of exteriority into the interiority of time, and by contaminating the isolated metaphysical present it comes to function as the concept that underlies the central notion of différance. ${ }^{55}$

The idea of spectrality in Specters of Marx should thus be understood as a highly radical and political elaboration by the later Derrida of his early deconstructive thinking. Warren Montag rightly claims that the possibility of spectrality in the first place depends on Derrida's concept of the "trace," which cannot be summed up in the simplicity of a present. "It is thus irreducible to a present or presence which might become a past or absence: its very noncontemporaneity determines the possibility of its persistence.”56 “A spectral moment,” according to Derrida, indeed does not fit into time, at least not into time conceived as a series of modalized presents (past present, actual present, and future present). The "specter” is, thus, firmly based on Derrida's deconstruction of metaphysical time. The present is "out of joint” because it fuses and

$$
{ }^{54} \text { Ibid., } 56 .
$$

${ }^{55}$ Rapaport is right when he claims that "La différance" could be considered a fragment or missing portion of “Ousia et Gramme" (Rapaport, Time and Language, 57). For a clear exposition on the "economy of exteriority” in Derrida's concept of time, see Protevi, Time and Exteriority.

${ }^{56}$ Warren Montag, “Spirits Armed and Unarmed: Derrida’s Specters of Marx," in Ghostly Demarcations: A Symposium on Jacques Derrida's Specters of Marx, ed. Michael Sprinker (London: Verso, 1999), 71-74. 
incorporates elements coming from the past and the future; it is always haunted by ghosts or revenants. As Fredric Jameson comments, spectrality could easily be described as what makes the present waver: like the vibrations of a heat wave through which the massiveness of the object world—indeed of matter itself—now shimmers like a mirage. ... Derrida's ghosts are these moments in which the present-and above all our current present, the wealthy, sunny, gleaming world of the post-modern and the end of history, of the new world system of late capitalism—unexpectedly betrays us. ${ }^{57}$

Ghosts introduce a constant "anachrony” into the present; they provoke an "untimeliness and disadjustment of the contemporary." ${ }^{58}$ The specter, therefore, is not just a piece of the "traumatic" past popping up into the present; rather, its logic questions the whole traditional relationship between past, present, and future.

While Specters of Marx logically elaborates on Derrida's lifelong project of deconstruction, it also includes something affirmative. The figure of the specter must justify the passage from a "technico-ontological” disadjustment of time to a problematic of justice that cannot be grasped in terms of ontology. ${ }^{59}$ Derrida is clear about why he used the figure of the specter: "If I am getting ready to speak at length about ghosts, inheritance, and generations, generations of ghosts, which is to say about certain others who are not present, nor presently living, either to us, in us, or outside us, it is in the name of justice.” ${ }^{60}$ Absolute presence or essence, according to Derrida, never has been the condition or the object of justice; justice always assumes a certain sense of anachronism. Ethics cannot restrict itself to the present and the living generations. One must always remember that the impossible (to let the dead bury their

\footnotetext{
${ }^{57}$ Fredric Jameson, “Marx’s Purloined Letter,” New Left Review 209 (1995), 85-86.

${ }^{58}$ Derrida, Specters of Marx, 99.

${ }^{59}$ Ibid.,19.

${ }^{60}$ Ibid., xix.
} 
dead) can happen; that, for Derrida, is the possibility of absolute evil: an absolute presence that does not want to hear about death. Derrida's concern should be related to its late capitalist context with its strong repression of the past. ${ }^{61}$ His critique directly addresses Fukuyama and his end-of-history idea that declares the death of the past and tries to exorcise all specters in the name of an absolute present. That Derrida's chronosophy is related intimately to a politics of memory becomes very clear when he approvingly quotes Yosef Hayim Yerushalmi’s rhetorical question 'whether it is possible that the antonym of 'forgetting' is not 'remembering,' but justice.”62 Just like Benjamin, Derrida fiercely resists the reigning teleological time of progress, wherein past and present injustice can always be justified or legitimized by referring to a future catharsis. Only the promise of memorizing the unjust and the memorization of the promise of justice can counter such a totalitarian and immoral instrumental logic. ${ }^{63}$

\section{CONCLUSION}

It does not seem as though the century-old debate about whether it is more just or moral to focus on the past or to think about the needs of the present and the future can actually be resolved within traditional Western chronosophy. The concept of a singular time as an infinite continuum of fleeting presents that are absolutely synchronous to themselves forces us into a metaphysical binary logic of the present and the absent that, in its turn, gives rise to the notion that past and present are mutually exclusive. This logic is reflected in a strict division between the time of history and the time of jurisdiction, both unsatisfactory from a moral perspective because they

\footnotetext{
${ }^{61}$ Jameson, “Marx’s Purloined Letter,” 87.

${ }^{62}$ Cited in Jacques Derrida, Archive Fever: A Freudian Impression (Chicago: University of Chicago Press, 1996),
} 77.

${ }^{63}$ Matthias Fritsch, The Promise of Memory: History and Politics in Marx, Benjamin, and Derrida (Albany: State University of New York Press, 2005). 
leave us with the false choice between an almost economic logic of crime and punishment, on the one hand, and an excessive emphasis on absence and irreversibility that can be used in defense of impunity, on the other. The quest for alternative forms of justice, as manifested in the phenomenon of the truth commission, is all about resisting this forced choice between an oftenimpossible full retributive justice and a totally unacceptable plea for amnesia and blanket amnesty. That injustice has a clearly irreversible dimension can hardly be denied when the original victims and sometimes also the perpetrators are long dead. Still, it is precisely in the case of historical injustice that the problematic "presence” of the past becomes most apparent. The date of prescription that the law enforces undoubtedly has an important societal function, but it is artificial and certainly does not automatically banish the haunting past. The persistent stress on the endurance of historical injustice and the "presence" of the painful past therefore holds a central position in the quest for (symbolic) reparations or the struggle against impunity and preliminary prescription. It resists any simple opposition of a present temporal present and an absent/ontologically inferior past.

The analysis of Derrida helps us to see how both the time of history and the time of jurisdiction are in fact engaged in one and the same logic of presence. This logic posits the absent past as the modified presence of a past "present," and thereby at once posits the ontological inferiority of that past. The "metaphysics of presence” prevents historians from thoroughly thinking or even recognizing the spectral survival of the past, that is, from conceiving of any Being (Wesen) that is not and has never been a being in the present (An-Wesen). It is important not to isolate Derrida's idea of spectral survival from his deconstruction of the historical or "living” present. To understand his spectral logic one must relate it, as Jameson remarks, to the insight that the "living present is scarcely as self-sufficient as it claims to be; that we would do well not to count on its density and solidity, which might under exceptional 
circumstances betray us. ${ }^{\prime 64}$ Derrida stresses that his spectral logic does not introduce some kind of new metaphysical category. Rather, it is a logic that is implicitly needed in any critique of metaphysicalization, abstraction, idealization, ideologization, or fetishization. ${ }^{65}$ Spectrality cannot be dated-in a chain of presents, according to a calendar-but it surely is historical. As Montag writes, the specter is simply that which "was never alive enough to die, never present enough to become absent." ${ }^{, 66}$ In other words, spectrality or the denial of "full absence” is the logical other of Derrida's lifelong deconstruction of full presence.

This embeddedness in an explicit deconstruction of the "historical present" or in a "constitutive anachronism" as the condition for any survival of the past is missing in the recent discussion of presence. ${ }^{67}$ As a result, the "presence"-paradigm is never very clear about the "mode of being" of this "presence" of the past—doubting both materialist explanations and outright idealism—and does not clearly posit it as a firmly historical (while non-historicist) phenomenon. With the exception of Ewa Domanska's contribution, the debate never really questions the present/absent dichotomy. Sometimes the "presence" of the past is treated as the full presence that is the antonym of absence, thereby risking regression to the mythical reversibility of the time of jurisdiction. This can only lead to an obscure metaphysical or even mystical discourse, because a past that is fully "present in the present" can hardly be considered a past at all. This mysticism of the "presentists" has already been addressed in a (partly unfair but still worrisome) criticism by the Dutch historian Ed Jonker, who complains about its antirational and antiscientific tendencies and about its "Hegel-feeling" (Hegel-gevoel) that makes him feel

\footnotetext{
${ }^{64}$ Jameson, “Marx’s Purloined Letter,”, 86.

${ }^{65}$ Derrida, “Marx \& Sons,” in Sprinker, ed., Ghostly Demarcations, 245.

${ }^{66}$ Montag, “Spirits Armed and Unarmed,” 74.

${ }^{67}$ The term constitutive anachronism comes from Ernesto Laclau, “The Time is out of Joint,” Diacritics 25:2
} (1995), 88. 
dizzy. ${ }^{68}$ To be fair, one should differentiate between Runia’s thoughtful use of the "presence"paradigm to analyze the phenomena of commemorations, monuments, and the naming of the dead—often driven by a longing for the full-presence of the past—and his more problematic analysis of the survival of the past itself. ${ }^{69}$ The latter analysis is closely related to his attempt to reverse the classical subject/object relation, leading him to evoke a past that is not prefigured or constructed by historians but that takes control of them itself. ${ }^{70}$ In his study of the Dutch Srebrenica report—which he considers to be a case study of presence-Runia's description of the way the past overpowers the historians of the NIOD [Netherlands Institute for War Documentation] is highly idealistic, and outside of that philosophical tradition it is difficult to comprehend his and Ankermit's claim that it involves a literal repetition of the past, that we get "the real thing” twice. ${ }^{71}$ The mystical agency that Runia accords to the present past becomes very clear in the strange argument that the presence of past torture in Abu Ghraib prison made the American soldiers repeat it. ${ }^{72}$ Runia thus fails to see how his analysis of presence as the "the unrepresented way the past is present in the present” should in fact be turned back on itself in order to question the concepts of past and present themselves. ${ }^{73}$

${ }^{68}$ Ed Jonker, “Presence: de stijlfiguur van het déjà vu,” Tijdschrift voor geschiedenis 119:2 (2006), 249-254.

${ }^{69}$ For Runia's further elaboration on the metonymical ritual of naming the names of victims, see Eelco Runia, “Namen Noemen,” Tijdschrift voor geschiedenis 119:2 (2006) 242-248.

${ }^{70}$ For an analysis of this anti-Cartesian and anti-epistemological reversal in the "presence"-paradigm, which posits the primacy of the object instead of the subject, see L. ter Schure, "De tegenwoordigheid van het verleden in het heden," Tijdschrift voor geschiedenis 119:2 (2006 230-41.

${ }^{71}$ Eelco Runia, “'Forget about it’: Parallel Processing in the Srebrenica Report,” History and Theory 43 (2004), 295-320; and Frank Ankersmit, “'Presence’ and Myth,” History and Theory 45 (2006), 332.

${ }^{72}$ Eelco Runia, “Spots of Time,” History and Theory 45 (2006), 308.

${ }^{73}$ Eelco Runia, “Presence,” History and Theory 45 (2006) 5. 
Domanska goes a good deal further when she deconstructs the present/absent dichotomy, by referring to "things" (the dead body, for example) that resist this dichotomous classification. Her Heideggerian analysis is very subtle when she claims that we must recognize the presence of nonhuman actors and that this presence should not only be taken to mean that they are present. ${ }^{74}$ Still, she does not take this possibility of a "presence" that resists the present/absent dichotomy back to its complex relation to a subverted temporal present that is "out of joint.” As a result, she admits that her project of "Heideggerian or contemplative archaeology," which must serve as an alternative for the omnipresent discussions about narrative and representation, "might be regarded as another (desperate) attempt to find an extraneous (transcendental) power (Being), a project haunted by metaphysical phantoms lingering in the humanities.”75

The spectral survival of dimensions of the past that I have defended here (in my slightly Althusserian reading of Derrida or Derridian reading of Althusser) would possess properties quite opposite to those that Runia describes. The spectrality would not be the sudden “revolutionary," "sublime,” and "mysterious” presence of things that some time before had “awesomely suddenly" ceased to exist. Instead, it would be a "non-agentic" noncontemporaneity that occurs simply because it is impossible for some phenomenon to cease suddenly or simply to become absent. Spectral logic questions the self-evidence of modernity's claim to be able to accomplish (and constantly renew) a radical and clear break with the past in order to start from the ground up to create a new present or new time (see Koselleck's neue Zeit). Every attempt to produce such a clear break with the past and a new beginning (such as is done symbolically when one writes a new constitution to give a new identity to a nation) will be frustrated by the reality of the historical process that resists being frozen and always contains delays, survivals, and unfinished projects. Spectrality is all about mourning and (desired or not)

\footnotetext{
${ }^{74}$ Ewa Domanska, “The Material Presence of the Past,” History and Theory 45 (2006), 348.

${ }^{75}$ Ewa Domanska, “Toward the Archaeontology of the Dead Body,” Rethinking History 9:4 (2005) 396.
} 
inheritance. It can shed special light on the problematic and complex relations to the past in situations where societies in transition try to carry on with life after violent conflict. But spectral survival is certainly not exceptional. As Derrida puts it, "synchrony does not have a chance, no time is contemporary with itself,” and neither revolution nor social transition can easily do away with this fact. ${ }^{76}$

All this being said, let us get back to Nietzsche, Benjamin, and the transitional justice dilemma so that we can see what can and what cannot be said about them now that we have criticized metaphysical time and have learned about spectrality. Unfortunately, simply recognizing the spectral survival of the past and the non-contemporaneity of the living present cannot solve the dilemma of the temporal direction of ethics. Ernesto Laclau correctly observes that one cannot legitimately make the logical transition from a (post-)ontological claim about specters and the disadjustment of time to a binding ethical injunction to be responsible to them. ${ }^{77}$ The spectral logic cannot decide on how exactly to deal with the past after political transition, and/or violent conflict will stay a sociopolitical issue that cannot be solved a priori and out of context. Recognition of spectrality can, however, unmask the transitional justice dilemma as a discussion that is based on false premises. It gets rid of the presumed ontological inferiority of the past that determines the unequal relation between the preoccupation with historical injustice, on the one hand, and values directed solely at the present and the future, on the other. This allows one to resist Nietzsche's exoteric argument that presents a false choice between a living present and a dead and absent past. At the same time, spectral logic and its deconstruction of the living present allow us to re-evaluate Benjamin’s “anamnestic solidarity” apart from the Jewish mysticism that is often related to it. As Laclau remarks, the ethical significance of such a

\footnotetext{
${ }^{76}$ Derrida, Specters of Marx, 111.

${ }^{77}$ Laclau, “The Time Is out of Joint,” 93.
} 
deconstructive movement "is that by enlarging the area of structural undecidability it enlarges also the area of responsibility—-that is, of the decision.”78

Historians, then, can create a more substantial ethical mandate for history and can significantly contribute to the debate on the spectral survival of the past by contesting the notion of a stable, autonomous present and the omnipotence of absolute presence. Deconstructing the living present will be a painstaking and highly introspective operation for historians, however, because their entire profession is deeply engaged in the metaphysics of presence. To develop an alternative historiographical practice they must first dismiss the metaphysical idea of a devouring, pointillist time as a collective singular. Next they must rethink some central notions, for example "event” and "anachronism,” so that they can break free from simplistic chronology. The task of simultaneously creating and unmasking time would be in line with the thinking of Collingwood, who respectively saw history as an antimetaphysical "science of absolute presuppositions,” or Horkheimer, who stressed that history should oppose metaphysics because of its conservative eternalizing of the existing state of affairs. ${ }^{79}$

In conclusion, Henry Rousso makes a point when he situates the liberating character of history in its rejection of the idea that people or societies are conditioned or determined by their past without any possibility of escaping it. Derrida also was right when he stressed the danger of deserting the past and the horrific image of a time that isolates itself, announces the end of history, and thereby cancels the struggle for historical justice or defers it eternally. ${ }^{80}$ Historians thus must recognize the tyranny of "everlasting pasts" ${ }^{81}$ as well as expose the forever-returning

${ }^{78}$ Ibid., 94.

${ }^{79}$ R. G. Collingwood, An Essay on Metaphysics (Oxford: Oxford University Press, 1998); and Max Horkheimer, “On Bergson’s Metaphysics of Time,” Radical Philosophy 131 (2005), 12.

${ }^{80}$ Rousso, The Haunting Past, 28.

${ }^{81}$ Term from Eric Conan and Henry Rousso, Vichy, un Passé qui ne passe pas (Paris: Fayard, 1994). 
Published in History and Theory, 47 (2008), 2, pp. 149-167.

tendency to formulate triumphalist "eternal presents" (that is, the idea of "end of history" by Fukuyama and many others ${ }^{82}$ ). Only in such a way can historians begin to bring together the time of history and the time of jurisdiction.

University of Gent, Belgium

${ }^{82}$ See Lutz Niethammer, Posthistoire: Has History Come to an End? (London: Verso, 1992). 